ISSN 1112-9867

http://www.jfas.info

\title{
PREDICTION OF CRITICAL THINKING DISPOSITION BASED ON MENTORING AMONG FACULTY MEMBERS
}

\author{
M. A. Behzadi ${ }^{1}$, N. Noushadi ${ }^{2, *}$ \\ ${ }^{1}$ M.A student in Educational Research, Yasouj University, Yasouj, Iran \\ ${ }^{2}$ Department of Psychology, Yasouj University, Yasouj, Iran
}

Published online: 18 July 2016

\begin{abstract}
This study attempted to see if there is any relationship between Mentoring and critical thinking disposition among faculty members and predict critical thinking disposition based on faculty members mentoring. The study population is all full-time faculty members of Isfahan University as 500 in academic year 2013-2014. To this end, a random sample of 217 faculty members was selected. The following scales were applied: critical thinking disposition (Ricketts, 2003) and Mentoring scale (Based on Anderson and Shannon mentoring principles, 1988).The validity of scales was computed with factor analysis by confirmatory method and alpha coefficients for determining the reliability of each variable were as follows: Critical thinking disposition $(\alpha=.95)$ and Mentoring $(\alpha=.82)$. The results of study showed that there was a significantly positive correlation between Mentoring and Critical thinking disposition among faculty members. The findings showed that $67 \%$ of variance of critical thinking disposition was defined by predictive variables. The faculty members evaluated themselves in all mentoring and critical thinking lower than desirable level.
\end{abstract}

Keywords: Mentoring, Critical thinking disposition, Faculty members

Author Correspondence, e-mail: noshadi5@ hotmail.com

doi: http://dx.doi.org/10.4314/jfas.v8i2s.145 


\section{INTRODUCTION}

Mentoring is a term applied widely at work and academic environment and it plays important role in practical learning (Fullerton, 1998). This process is a professional sociability by which an experience person as a mentor guidance to low experience person as Mentee or Protégé (Jacobi, 1991). Mentoring is a unique relation in which people can share their personal experiences and skills and growth and it is a kind of collaboration between the mentor and mentee focusing on mentee growth (Campbell and Campbell, 2000). Mentoring is beyond teaching or transferring information and the mentee trust is increased regarding his capabilities and its aim is increasing learning, growth in a mutual relationship (Allen, 2003).

Mentoring is a regular and complex process in which an experienced person supports, encourages and teaches an unexperienced person. In this process, the mentor supervises the mentee growth and helps him/her to believe his/her profession and personal capabilities. For ten years, mentoring is used in most Universities around the world and it is also used in scientific, educational, job and commercial fields (Wilson, Pereira and Valentine, 2002). But, the academic mentoring focuses mostly on development of knowledge and research skills of students (Marshal, Adams, Cameron, 2004).

The basic concept in mentoring is creating communicative synergy and synergy is the underlying concept in the team (Murphy \& Lick, 1998). Mentoring is a supportive, guider, consulting and critic of mentee to achieve learning goals (Vanzant, 1980). The relationship between mentor and mentee leads to synergy as creating passion learning and common concept for progress (Covey, 1990). The prerequisite of passion learning is ability, capacity to share goals between the mentor and mentee (Conner, 1993). Such approach provides empathy and it means perceiving each other and sharing others emotions. And critical thinking preparing teachers for empathy with students. The important point in the present world is that teachers and students as critical thinkers to become lifelong learning. The requirement of a productive mentoring is critical thinking disposition component such as open-mindedness and respecting the opposite beliefs and fair-mindedness. 


\section{STATEMENT OF PROBLEM}

Every year, the students of universities are increased and their satisfaction of higher education is one of the qualities indices of assessment of higher education. One of the main indices of most of universities is the students and graduates satisfaction of faculty members mentoring system. The faculty attitude should be friendly and views the student as mentee (future co-worker) and critical thinking is created in this way. Baueelein (2015) showed that combining critical thinking and mentoring led into extension of philosophy of life for the mentee. He showed that 33 percent of students report that they never talk with professors outside of class, while 42 percent do so only sometimes and 25 percent never talking with faculty members. He found that mentoring of faculty members led into developing critical thinking among students. In the current world, educational paradigm is changing from training for employment to training to nurture potentials. Therefore, the educational institutes should nurture the people for recognition, problem solving, communication skills and decision making via critical thinking. Today, some experts consider critical thinking as the major goal of education and academic experience (Mangena \& Chabeli, 2005). Most of theoretical frameworks of mentoring emphasize on the critical discussion between the mentor and mentee. Mooney\& Moles (2012) in a critically reflective mentor framework, referred to critical thinking, caring and professional agency. They defined mentoring as a complex intellectual, social and emotional construct with the capacity for professional support, learning and professional knowledge generation within the context in which it is practiced and within broader societal norms and values. Therefore, mentor teacher as critical thinker, professional carer and as professional agent. According to Bernstein (2000), the goal of educational system is developing global citizens with ethical mission. This is a part of teaching jobs. He considers the teacher mission as mentoring with critical approach to evaluate teaching reflective thinking view in mentee. Noddings (2007) referred to the relationship between mentoring and critical and caring thinking to create social changes in the current world. Brookfield (1995) showed that mentors were critical in the followings: 1The disposition to research in thought and practice of mentor and mentee, 2- sharing insights with the mentee (as the friend of critic), 3- receiving feedback of mentee. 
Many studies showed that critical awareness of students under the mentor teachers were much more than other students as they had multidisciplinary approach and held strong workshop and selected exact topics and were skilled questioners. Then, mentor-mentee approach based on critical thinking leads to spiritual edification. Because, by asking critical questions, the mentor can help the mentee to learn three skills: communication, decision making and problem solving. The mentee learns to challenge his/her ideas with the question "Do I have some evidences for my Ideas?" and if the answer is no, wrong ideas are discarded. Thus, the mentor-mentee relationship is effective on the interpersonal and intrapersonal relation. This approach leads to self-reflective and self-transformation skills in mentee.

\section{HISTORICAL APPROACH TO MENTORING}

The story of Mentor comes from Homer's Odyssey. Odysseus, king of Ithaca, leaves to fight in the Trojan War, he entrusts the care and teaching of his son, Telemachus, to his friend, Mentor. Over time, the word Mentor evolved to mean trusted advisor, friend, teacher and wise person (Shea, 2002).

The account of Mentor in The Odyssey leads us to make several conclusions about the activity which bears his name. First, mentoring is an intentional process, Second mentoring is a nurturing process. Third, mentoring is an insightful process in which wisdom of the mentor is acquired and applied by the mentee. Fourth, mentoring is a supportive, protective process (Clawson, 1980).

A new English dictionary (Murray, 1908), documents various uses of the term "mentor" dating from around 1750. Anderson and Shannon (1988) studied evolutionally transformation of mentor concept. They found that the first meaning for mentor belong to professional career that related to Human Resource Development Movement in business. Philips-Jones (1982) define mentors in six types: Traditionally mentors are usually older authority figures who, over a long period of time, protect, advocate for and nurture their mentee. Supportive bosses are persons in a direct supervisory relationship with their mentee. Organizational sponsors are top level managers who see that their mentee are promoted within the organization. 
Professional mentors comprise a variety of career counselors and advisors. Patrons are persons who use their financial resources and status to help mentee prepare for and launch their careers. Invisible godparents help mentee reach career goals without their knowing it.

Alleman (1986) believed that mentors are teachers, advisors, guiders and developers of creativity of mentee. She identifies nine mentor function: giving information, providing political information, challenging assignments, counseling, helping with career moves, developing trust, showcasing mentee achievement, protecting and developing personal relationship/friendship. Anderson (1987) proposed that mentoring is a nurturing process based on caring relationship between mentor and mentee.

In the last approach to mentoring concepts, Mooney\& Moles (2011) redefines the concept of mentoring of critical thinking and caring at the same time in mentoring and considered mentoring as critical and reflective teaching to mentee. From this view, mentoring is defined as critical thinking of mentor-mentee answering this question "Whether the teachers are involved in critical thinking in their teachings?"

\section{MENTORING AND CRITICAL THINKING}

The studies of the past forty years on field study of Bloom showed the relationship between mentoring and critical thinking. The researchers have found that achieving high cognitive level of Bloom is based on mentoring goals and supporting mentee to help them to achieve lifelong learning skills and turning them to independent thinkers as the main critical thinking factors (Paul, 1985). To achieve the high educational goals namely for continuous development of critical thinking and creative thought of students, new educational and communicative methods between the teacher and student are necessary. This aim is achieved with the deep relationship and continuous feedback between the teacher and student in a dynamic mentoring relationship (Terry and Lusiana, 2011).

In mentoring relationship, the highest focus should be on critical thinking and this is achieved via emotional relationship between the mentor and mentee (Thomas, 2006). Alisson and Williams (2012) believed that the mentor had some features helping the 
mentee. The features include asking wise questions, active listening, presenting role model, self-change facilitating and showing critical thinking. By asking purposeful questions and effective feedbacks, the mentor helps the mentee to learn this listening style and helps him/her to achieve skills in decision making and problem solving. The mentors taking benefit of their personal experience and life of critical thinking, can better have the role model of a critical thinker for their mentee. If the teacher provides effective feedbacks for their student as mentee, critical thinking is showed and a desirable model of a critical thinker is also represented. If the mentee works on the road map and goals, the teacher as a mentor by involving him/her in critical discussions can improve his/her critical thinking (Lillian and colleagues, 2007).

Maynard \& Furlong (1995) identified three distinct mentoring models: a) apprenticeship, competency and reflective model. In apprenticeship model, the mentor is emerged as a role model. In competency model, the mentor as a systematic teacher by explaining the duties educates the mentee to achieve organizational competencies. In reflective model, the mentor acts as a critical friend and co-inquirer.

Also, Mooney \& Moles (2012) in their model "Productive mentoring" showed that caring functions and professional attitude are performed by mentors but mentors have no inclination to critical thinking.

Mooney \& Moles (2011) with ethical-rational view presented a framework based on critical thinking of mentor-mentee and caring and professional effort were at the center of this model. Thus, a mentor as a critical reflective provides the capacity of criterial thinking disposition.

\section{RESEARCH QUESTIONS}

1- Is there any significant relationship between mentoring and critical thinking disposition?

2- How much is mentoring competence of faculty members?

3- How much is the critical thinking disposition of faculty members? 


\section{POPULATION AND SAMPLE}

A random sample of 217 faculty members in Isfahan University were selected and implemented the scale of critical thinking disposition Ricketts (2003) and self-made scale of Mentoring competence based on Anderson and Shannon (1988). For analysis of data used SPSS software.

\section{RELIABILITY AND VALIDITY}

In the present study, reliability by Cronbach's alpha for mentoring scale is $\alpha=0.82$ and for critical thinking disposition $\alpha=0.95$. To evaluate validity, confirmatory factor analysis is used and K.M.O=0.81 and Bartlett's test is significant at the level $\mathrm{P}<0.001$ for mentoring scale and for critical thinking disposition, K.M.O=0.94 and Bartlett's test is significant at the level $\mathrm{P}<0.001$

\section{RESULTS}

First question: Is there any significant relationship between mentoring and critical thinking disposition?

Table 1. Pearson correlation coefficient between mentoring and critical thinking disposition

\begin{tabular}{l|l}
\hline Variable & Mentoring \\
\hline Critical thinking disposition & $.62 * *$ \\
\hline
\end{tabular}

Significant at the level $0.01 * *$

As shown in Table 1, there is a positive and significant relationship at the level $\mathrm{P}<0.01$ between two variables of mentoring and critical thinking disposition in the entire sample. 
Table 2. Pearson correlation coefficient between the subscales of mentoring and critical thinking.

\begin{tabular}{|c|c|c|c|c|c|c|c|c|}
\hline variable & 1 & 2 & 3 & 4 & 5 & 6 & $\mathbf{M}$ & $\mathbf{S}$ \\
\hline Creativity & 1 & & & & & & 23 & 3.90 \\
\hline \multirow[t]{2}{*}{ Cognitive maturity } & $0.54 * *$ & 1 & & & & & 23.0 & 4.56 \\
\hline & & & & & & & 2 & \\
\hline \multirow[t]{2}{*}{ Engagement } & $0.57 * *$ & $0.73 * *$ & 1 & & & & 68.9 & 21.6 \\
\hline & & & & & & & 3 & 0 \\
\hline \multirow[t]{2}{*}{ Guidance } & $0.49 * *$ & $0.55 * *$ & $0.83 * *$ & 1 & & & 32.5 & 7.56 \\
\hline & & & & & & & 0 & \\
\hline \multirow[t]{2}{*}{ Insight } & $0.14^{*}$ & $0.27 * *$ & 0.05 & 0.03 & 1 & & 66.6 & 8.64 \\
\hline & & & & & & & 0 & \\
\hline \multirow[t]{2}{*}{ Human relations } & 0.11 & $0.14^{*}$ & $0.27 * *$ & $0.23 * *$ & .03 & 1 & 24.2 & 5.47 \\
\hline & & & & & & & 8 & \\
\hline
\end{tabular}

**Significance at the level 0.01

* Significance at the level 0.05

Table 3. Regression model of mentoring based on critical thinking disposition.

\begin{tabular}{|l|c|l|c|l|l|l|l|}
\hline Model & Sum of squares & df & Mean of squares & $\mathbf{R}$ & $\boldsymbol{R}^{2}$ & $\mathbf{F}$ & Sig \\
\hline Regression & 110032.53 & 3 & 36677.51 & .82 & .67 & 142.45 & .001 \\
\hline Residual & 54841.17 & 213 & 257.47 & & & & \\
\hline
\end{tabular}

Table 4. The statistical feature of regression of mentoring with critical thinking disposition.

\begin{tabular}{|l|c|c|c|c|}
\hline \multicolumn{1}{|c|}{ Predictive variables } & B & Beta & t & p \\
\hline Insight & 0.26 & 0.08 & 2.05 & 0.04 \\
\hline Guidance & 2.89 & 0.79 & 19.43 & 0.001 \\
\hline Human relations & 0.35 & 0.06 & 1.70 & 0.09 \\
\hline
\end{tabular}


As shown in the results of Tables 3, 4, multiple correlation coefficient is 0.82 and it shows that three components of mentoring 0.82 had correlation with critical thinking disposition. The coefficient of determination is 0.67 and it shows that $67 \%$ of variance of critical thinking disposition is explained via independent variables. To define which components of mentoring has high share in explanation of critical thinking disposition of faculty members, standard regression (Beta) is applied. Based on the results of Table, guidance with Beta 0.79 and Insight with Beta 0.08 have positive and significant share in prediction of critical thinking disposition. It is worth to mention that human relations component had no significant share in prediction of critical thinking disposition of faculty members.

\section{Second question: How much is the mentoring competence of faculty members?}

To respond this question, one sample t-test is applied. Tables 5, 6 show the comparison of mean of mentoring dimensions compared to middle criterion (Q2). It can be said that faculty members evaluate human relations and insight lower than average. The faculty members evaluated themselves as average in guidance component. The faculty members evaluated lower than desirable (Q3) in all mentoring dimensions.

Table 5. The comparison of the mean of dimensions of mentoring with average criterion

\begin{tabular}{|l|c|c|c|c|c|c|c|}
\hline \multicolumn{1}{|c|}{ Variable } & $\mathbf{N}$ & $\mathbf{M}$ & $\mathbf{S D}$ & $\mathbf{Q 2}$ & $\mathbf{t}$ & $\mathbf{d f}$ & Sig \\
\hline Insight & 217 & 32.50 & 7.56 & $\mathbf{3 2}$ & .98 & 216 & .32 \\
\hline Guidance & 217 & 66.60 & 8.64 & $\mathbf{6 8}$ & 2.38 & 216 & .01 \\
\hline Human relations & 217 & 24.28 & 5.47 & $\mathbf{2 6}$ & 4.61 & 216 & .001 \\
\hline
\end{tabular}

Table 6. The comparison of the mean of mentoring with desirable criterion

\begin{tabular}{|l|c|c|c|c|c|c|c|}
\hline \multicolumn{1}{|c|}{ Variable } & N & M & SD & Q3 & t & df & Sig \\
\hline Insight & 217 & 32.50 & 7.56 & $\mathbf{3 9}$ & 12.65 & 216 & .001 \\
\hline Guidance & 217 & 66.60 & 8.64 & $\mathbf{7 3}$ & 10.91 & 216 & .001 \\
\hline Human relations & 217 & 24.28 & 5.47 & $\mathbf{2 9}$ & 12.68 & 216 & .001 \\
\hline
\end{tabular}




\section{Third question: How is the critical thinking disposition of faculty members?}

To respond this question, one sample t-test is used. Tables 7, 8 show the comparison of the mean of critical thinking disposition compared to middle criterion (Q2). The faculty members evaluated their cognitive maturity lower than average. It is worth to mention that teachers evaluated the creativity and engagement average. The faculty members evaluated the critical thinking disposition lower than desirable level (Q3).

Table 7. The comparison of the mean of critical thinking disposition with average criterion

\begin{tabular}{|l|c|c|c|c|c|c|c|}
\hline \multicolumn{1}{|c|}{ Variable } & N & M & SD & Q2 & t & df & Sig \\
\hline Creativity & 217 & 23 & 3.90 & $\mathbf{2 3}$ & .01 & 216 & .98 \\
\hline Cognitive maturity & 217 & 23.02 & 4.56 & $\mathbf{2 4}$ & 3.14 & 216 & .01 \\
\hline Engagement & 217 & 68.93 & 21.60 & $\mathbf{6 8}$ & .63 & 216 & .53 \\
\hline
\end{tabular}

Table 8. The comparison of the mean of critical thinking disposition with desirable criterion

\begin{tabular}{|l|c|c|c|c|c|c|c|}
\hline \multicolumn{1}{|c|}{ Variable } & N & M & SD & $\mathbf{Q 3}$ & $\mathbf{t}$ & df & Sig \\
\hline Creativity & 217 & 23 & 3.90 & $\mathbf{2 6}$ & 11.30 & 216 & .001 \\
\hline Cognitive maturity & 217 & 23.02 & 4.56 & $\mathbf{2 6}$ & 9.59 & 216 & .001 \\
\hline Engagement & 217 & 68.93 & 21.60 & $\mathbf{8 8}$ & 13 & 216 & .001 \\
\hline
\end{tabular}

\section{DISCUSSION}

The fundamental question of mentoring in higher education is: What kind of University we should have to share the student in issues and make a hopeful image? At the age the students enter University, they should define themselves but as they cannot do this, they act as an adolescent. University should provide an opportunity for students to take benefit of mature communities. If teachers impose work with students in University, they work imposed at society in future and they don't see others and Assign a special right for themselves.

Education not only as teaching but also as love and faith in spirit of adolescents. In other words, education is soul inquiry. Gadamer (2000) criticized Aristotle linear view and said the most important dimension of human thinking opens itself up in this beginning if we know that 
potentially is always the possibility open in the sense of an orientation toward an indeterminate future.

Freire (1970) criticized "banking concept of knowledge" and considered teacher as a mentor for critical informing. Teacher is not a person teaching, he can learn in the classroom with other students. The teacher and students are responsible for their development. He considered the goal of education increasing critical awareness of learners to think freely or give opinion about what they seen at social or cultural environment. Popper (1977) believed that teacher shouldn't impose the values on students, and their interest to the values should be motivated. Teacher should be the friend of student but variety of learners is a big barrier to fulfil such aim and its outcome is the lack of thought independence of learners. Mentoring is the relationship between two people with the aim of learning and development (Megginson and Garvey, 2004).

Based on the condition of educational system in Iran and namely low socio-economic condition of the most of students, mentoring can decrease one's change time and increased self-esteem of students.

Evolving concept of mentoring is emphasized and teacher as a mentor directs a person in autonomy of mind and in the last step, he is independent to be turned into a mentor and he/she can have independent life. Thus, the teacher doesn't try to produce a similar person (Chart 1).

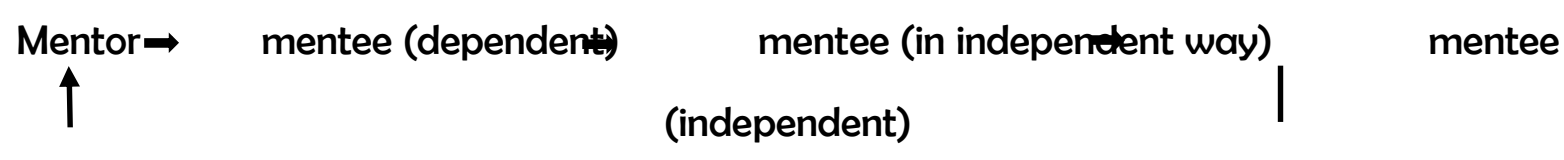

Chart 1. The path process of mentor-mentee

Regarding the findings of present study, guidance has the highest share and human relations as the lowest share. For explanation of this findings we can use "Theory of institutions" by North (1993). The institutions determine rule of game in society or they are the rules developed by the human being to forming the mutual relationship of people with each other. The institutional changes are the key of communicative changes. Thus, the perception of institutional framework prepares the understanding of human being.

In Iran, the highest relationship between the teacher and student in University is regarding 
research issues. Based on the quantitative growth of students and low quality of educational issues. Institutional constraints obliged faculty members to dedicate to research works and less developing the students.

Another findings of this study is the component of human relations had no positive and significant predictability critical thinking disposition. It seems that the outcome of these institutional constraints is two threats endangering Iranian Universities: 1- the increase in the number of universities, 2- circularizing thought. It means that by increasing the number of Universities, administrative and mechanical thought is dominated and University is turned into a machine to form students. Regarding these findings, we can say the faculty members observed guidance factor more in terms of supervision of thesis or papers and this relationship is defined only based on the development of teacher than student growth.

We can say the teachers by teacher-student relationship are mostly try to promote their position for associate professor or professor instead of perceiving the student views and their growth. Such approach leads to quantitative growth of student. Thus, the quantitative growth of students should be on priority. University is not just for preparing the student for test or exam. University should play a creative role in education of the youth. It means that the student and teacher should be dynamic. Those working in different fields should inspire each other. Thus, higher education institute should provide mentoring as "students and teachers talk as they only want to secure their own nature". It seems that the outcome of the present institution constraint in higher education is contrast with its existence.

Due to mentoring weakness in higher education system of Iran, graduates may be define their personality in contrast to other characters and the view is top to down. The student shouldn't only develop in his/her own field. The most important duty of teachers is considering educational ideal and protection of educational values and defending freedom and autonomy. The productive mentors know that the student destiny is determined not only in exams but in create critical thinking. 


\section{REFERENCES}

- Alleman, E. Measuring mentoring frequency quality impact. Mentoring: Aid to excellence in career development, business and the professions. 1986, Pp. 44-51. British Colombia.

- Allen, S. Mentoring the essential connection. AORN Journal, 2003, Online.<http://www.findarticle.com>.

- Allison, E., Williams, M. Mentor Handbook. Mentoring Resource center. Wake Forest University, 2012: 14-28.

- Anderson, E. Definitions of mentoring. Sacramento: California State Department of Education, 1987.

- Anderson, E. M., Shannon, A. L. Toward a conceptualization of mentoring. Gornal of teacher Education, 1988, 1(39): 38.

- Baueelein, M. What's the point of a professor? The New York Times. MAY. 9. 2015.

- Bernstein, B. Pedagogy, Symbolic Control and Identity: Theory, Research, Critique. Oxford, 2000.

- Brookfield, S. Becoming a critically reflective teacher. San Francisco, CA: Jossey-Bass, 1995.

- Campbell, D. E., Campbell, T. A. The mentoring relationship: differing perceptions of benefits, College student Journal. [Online]. www.findarticle.com, 2000.

- Clawson, J. G. Mentoring in managerial careers. Work, Family, and the career. pp. 144-165. New York: Prager, 1980.

- Conner, D.R. Managing at speed of change. New York. Villard, 1993.

- Covey, S. The seven habits of highly successful people. New York. Fireside, 1990

- Freire, P. Pedagogy of oppressed. London: Penguin Books, 1970.

- Fullerton, H. Facts of mentoring in higher education, 1998. [Online]. < www.Facts of Mentoring in Higher Education, html>.

- Gadamer, H. G. The Beginning of philosophy. Bloomsbury academic, 2000.

- Jacobi, M. Mentoring and undergraduate academic success: a literature review. Review of Educational Research, 1991, 61(4): 505-532. 
- Lillian T. Eby, Jeam. E. Rhodes, and Tammy, D. Allen. Definition and Evolution of mentoring. The Blackwell Handbook of mentoring. Blackwell Publishing, 2007: 7-21.

- Mangena, A., \& Chabeli, M. M. Strategies to overcome obstacles in the facilitation of critical thinking in nursing education. Nurse Educe Today, 2005, 25(4): 291-298.

- Marshal, S., Adams, M., Cameron, A. Mentoring academic staff: lessons from the field, Macquarie University, Sydney Australia, 2004.

- $\quad$ Maynard, T., \& Furlong, J. Learning to teach and models of mentoring. In T. Kerry \& A. S. Mayes (Eds.), Issues in mentoring. Buckingham: The Open University, 1995.

- Megginson, D and Garvey, B. Odysseus, Telemachus and Mentor: stumbling into, searching for and signposting the road to desire, International Journal of Mentoring and Coaching, 2. (1), www. emccouncil.org [accessed20 February 2005].

- Mooney, G, S., \& Moles, J. Critical Thinking, Caring and Professional Agency: An Emerging Framework for Productive mentoring. 2011: 462-483.

- Mooney, G, S., \& Moles, J. Educating the critically reflective mentor. The sage handbook of mentoring and coaching in education. London: Sage publication, 2012.

- Murphy, C.U, \& Lick, D.W. Whole Faculty study groups. Oaks, CA. Corvin, 1998.

- Noddings, N. When School Reform Goes Wrong. New York: Teacher College, Columbia University, 2007.

- North, Douglas C, "Institutions and Credible Commitment", JITE, 1993, 149(1): 11-23.

- Paul, R. W. Blooms taxonomy and critical thinking instruction. Educational Leadership, 1985, 42(8): 36-39.

- Philips-Joens, L. Establishing a formalized mentoring program, Training and development Journal, 1983, 37(2): 38-42.

- Popper, K. Open society and its enemies. PENN, Buchinghamshire, 1966.

- Ricketts, J. C. The efficacy of leadership development, critical thinking dispositions, and student academic performance on the critical thinking skills of selected youth leaders. Unpublished doctoral dissertation, University of Florida, Gainesville, 2003. Available at :http: //etd.fcla.edu/UF/UFE0000777/ricketts_j.pdf. 
- Shea, G. F. Mentoring: How to develop successful mentor behaviors. Menlo Park, CA: Crisp Learning, 2002.

- Terry, E. H., Lusiana J. L. Collateral opportunity for increased faculty collaboration and development through a mentored critical thinking and writing exercise in a dental school curriculum. Journal of the Scholarship of Teaching and Learning, 2011, 11(2): $52-63$.

- Vanzant, L. Achievement motivation and mentor relationship. Unpublished Doctoral Thesis. Texas State University, 1980.

- Wilson, P. P., Pereira A., Valentine, D. Perception of new social work faculty about mentoring experiences. Journal of social work Education, 2002, 38(2): 317.

\section{How to cite this article:}

Behzadi A M, Noushadi N. Prediction of critical thinking disposition based on mentoring among faculty members. J. Fundam. Appl. Sci., 2016, 8(2S), 1964-1978. 